Boise State University

ScholarWorks

Biology Faculty Publications and Presentations

Department of Biological Sciences

$2-1-2013$

Phytochemistry Predicts Habitat Selection by an Avian Herbivore at Multiple Spatial Scales

Graham G. Frye

Boise State University

John W. Connelly

Idaho Department of Fish and Game

David D. Musil

Idaho Department of Fish and Game

Jennifer S. Forbey

Boise State University 


\title{
Phytochemistry predicts habitat selection by an avian herbivore at multiple spatial scales
}

\author{
Graham G. Frye, ${ }^{1,4}$ John W. Connelly, ${ }^{2}$ David D. Musil, ${ }^{3}$ and Jennifer S. Forbey ${ }^{1}$ \\ ${ }^{1}$ Department of Biological Sciences, Boise State University, Boise, Idaho 83725 USA \\ ${ }^{2}$ Idaho Department of Fish and Game, Blackfoot, Idaho 83221 USA \\ ${ }^{3}$ Idaho Department of Fish and Game, Jerome, Idaho 83338 USA
}

\begin{abstract}
Animal habitat selection is a process that functions at multiple, hierarchically structured spatial scales. Thus multi-scale analyses should be the basis for inferences about factors driving the habitat selection process. Vertebrate herbivores forage selectively on the basis of phytochemistry, but few studies have investigated the influence of selective foraging (i.e., fine-scale habitat selection) on habitat selection at larger scales. We tested the hypothesis that phytochemistry is integral to the habitat selection process for vertebrate herbivores. We predicted that habitats selected at three spatial scales would be characterized by higher nutrient concentrations and lower concentrations of plant secondary metabolites (PSMs) than unused habitats. We used the Greater Sage-Grouse (Centrocercus urophasianus), an avian herbivore with a seasonally specialized diet of sagebrush, to test our hypothesis. Sage-Grouse selected a habitat type (black sagebrush, Artemisia nova) with lower PSM concentrations than the alternative (Wyoming big sagebrush, A. tridentata wyomingensis). Within black sagebrush habitat, Sage-Grouse selected patches and individual plants within those patches that were higher in nutrient concentrations and lower in PSM concentrations than those not used. Our results provide the first evidence for multi-scale habitat selection by an avian herbivore on the basis of phytochemistry, and they suggest that phytochemistry may be a fundamental driver of habitat selection for vertebrate herbivores.
\end{abstract}

Key words: Artemisia spp.; Centrocercus urophasianus; Greater Sage-Grouse; habitat selection; herbivory; monoterpenes; plant secondary metabolites; sagebrush; selective foraging; south-central Idaho, USA; spatial scale.

\section{INTRODUCTION}

Ecological processes function simultaneously within multiple, hierarchically structured spatial scales (Wiens 1989). Consequently, inferences about the factors that influence ecological pattern and process are conditional on the spatial scale under investigation (Kristan 2006). Coarse-scale studies may indicate the importance of a particular set of factors, whereas fine-scale studies may indicate influences of an entirely different set of factors (Wiens et al. 1986). Thus, a holistic understanding of ecological pattern and process requires information from multiple scales. Animal habitat selection is an ecological process that occurs at multiple scales (Johnson 1980). Coarse-scale measurements may yield inferences about habitat selection that differ from those made at a fine scale within the same system (e.g., Becker and Beissinger 2003). Although patterns of habitat selection at a single scale are often important, patterns observed consistently at multiple scales may provide

Manuscript received 26 July 2012; accepted 5 October 2012. Corresponding Editor (ad hoc): W. Wetzel.

${ }^{4}$ Present address: Department of Biology and Wildlife, University of Alaska, Faribanks, Alaska 99775-7000 USA. E-mail: ggfrye@rmf-inh.org more robust inferences about factors fundamentally driving the habitat selection process.

Vertebrate herbivores have been the focus of an increasing number of multi-scale habitat selection studies (e.g., Moore et al. 2010, Rearden et al. 2011), which have yielded insights that may have been lacking from single-scale investigations. However, few studies have directly considered the role of diet in habitat selection by herbivores, despite the importance of food quality to individual fitness (DeGabriel et al. 2009). Herbivore diets are constrained by the nutritional and defensive chemistry of plants (Marsh et al. 2005). Although typically abundant, plants are relatively low in nutrients (White 1978) and often contain defensive compounds (i.e., plant secondary metabolites, PSMs; Dearing et al. 2005). This combination places conflicting pressures on herbivores to maximize consumption of one plant constituent (i.e., nutrients), while simultaneously minimizing consumption of another (i.e., PSMs; Dearing et al. 2005). These conflicting pressures may shape the evolution of selective foraging strategies (Bryant and Kuropat 1980), which may then influence the process of herbivore habitat selection (Moore et al. 2010).

We tested the hypothesis that the defensive and nutritional chemistry of plants fundamentally influences 
habitat selection by vertebrate herbivores. We predicted that habitats selected at multiple scales would be characterized by high-nutrient and low-PSM plants. We used an avian herbivore with a seasonally specialized diet of high-PSM plants to test our hypothesis. The Greater Sage-Grouse (Centrocercus urophasianus; hereafter Sage-Grouse) is an herbivorous tetraonine with a specialized diet of sagebrush (Artemisia spp.) leaves from late autumn through early spring (Wallestad et al. 1975). Sagebrush foliage contains relatively high concentrations of PSMs (e.g., monoterpenes, sesquiterpene lactones, phenolics; Kelsey et al. 1982) and previous work has suggested that Sage-Grouse browse sagebrush selectively with respect to nutrients and PSMs (Remington and Braun 1985, Welch et al. 1988). We evaluated the effects of nutrients and PSMs on Sage-Grouse habitat selection at three spatial scales: (1) selection of sagebrush habitat type, (2) selection of patches within a given habitat type, and (3) selection of plants within a given patch (i.e., diet selection). Here, we provide the first evidence for multi-scale habitat selection by an avian herbivore on the basis of phytochemistry.

\section{Methods \\ Study site}

We conducted this study during the winter of 20102011 with a Sage-Grouse-sagebrush system in a $\sim 19000$ ha area of south-central Idaho, USA $\left(42^{\circ} 11^{\prime} \mathrm{N}, 114^{\circ} 46^{\prime}\right.$ $\mathrm{W})$. The study area was between 10 and 316 times the size of reported Sage-Grouse winter home ranges, depending on the individual bird and home range estimation method (Schroeder et al. 1999). Dominant vegetation at the study site was a mosaic of black sagebrush (Artemisia nova) and Wyoming big sagebrush (A. tridentata wyomingensis) stands with a mixture of native grasses, exotic grasses, and herbaceous vegetation in the understory. Elevations ranged from approximately $1550 \mathrm{~m}$ to $1750 \mathrm{~m}$ and average annual precipitation was $26.3 \mathrm{~cm}$. Winter high temperatures averaged $4.6^{\circ} \mathrm{C}$ and winter low temperatures averaged $-5.9^{\circ} \mathrm{C}$. Maximum snow depth observed during the study was $7.5 \mathrm{~cm}$, but snow cover was absent during the majority of the study period.

\section{Field methods}

We marked 38 Sage-Grouse with $\sim 17$ g necklace-style VHF radio transmitters during 2010 and 2011. During each of three winter sampling periods (23-30 January 2011, 6-13 February 2011, and 8-14 March 2011), we used radiotelemetry to locate randomly selected SageGrouse flocks containing radio-marked birds during daylight. Radio-marked grouse were located one to three times each during the study, but individuals were never located repeatedly within the same sampling period. We collected samples of browsed and nonbrowsed sagebrush plants at each flock location (hereafter, "used patch"). Browsed plants were defined as those with evidence of at least 10 fresh Sage-Grouse bite marks (Appendix A: Fig. A1). Non-browsed plants were defined as plants with (1) no evidence of SageGrouse browsing and (2) evidence of Sage-Grouse presence (tracks, droppings, and browsed plants) within $0.5 \mathrm{~m}$ of the plant. At each used patch $(n=55)$, clippings from three browsed and three non-browsed plants were collected and pooled to form a single browsed sample and a single non-browsed sample. Additionally, we generated random coordinates $(n=55)$ constrained by the boundaries of the study area. At each set of random coordinates (hereafter, "random patches"), we collected clippings from the three closest sagebrush plants and pooled them into a single sample. We did not observe evidence of Sage-Grouse presence (e.g., browsed sagebrush, fecal droppings, tracks) at random patches. All samples collected within a given used or random patch were conspecific with one another and with the dominant sagebrush taxon (Wyoming big sagebrush or black sagebrush). Structural vegetation measurements can affect Sage-Grouse habitat use (Connelly et al. 2000, Hagen et al. 2007), so we measured shrub canopy cover (Wambolt et al. 2006) and height along two perpendicular 30-m transects at each used and random patch to account for this effect.

\section{Laboratory methods}

We stored sagebrush samples in a $-20^{\circ} \mathrm{C}$ freezer, ground the leaves in liquid nitrogen using a mortar and pestle, and divided each sample into three subsamples. The first subsample was used to quantify individual monoterpenes via headspace gas chromatography (Appendix B). We identified individual monoterpenes using co-chromatography with known standards. The second subsample was used in a colorimetric assay to quantify total phenolic concentrations (Appendix C). The third subsample was dried and shipped to Dairy One Forage Laboratory (Ithaca, New York, USA) for analysis of crude protein content.

We used crude protein as a nutrient variable because it can affect herbivore foraging behavior and reproductive success (Mattson 1980). Nutrient concentrations were quantified as percentage of dry mass. We chose monoterpenes and phenolics as PSM variables because both classes of compounds exert deleterious effects (e.g., toxicity, increased energy expenditure, nutrient binding) on herbivores (Dearing et al. 2005) and occur in relatively high concentrations in sagebrush (Kelsey et al. 1982). Monoterpenes were quantified as area under the gas chromatogram curve/100 $\mu$ g dry mass (AUC/100 $\mu \mathrm{g}$; Appendix B), and total phenolic concentrations were quantified as $\mu \mathrm{mol}$ gallic acid equivalents/g dry mass (Appendix C).

\section{Statistical analysis}

Prior to fitting models, we used Fisher's exact test to examine our a priori belief that Sage-Grouse used black sagebrush habitat more than expected on the basis of availability. Starting with one nutrient covariate (crude

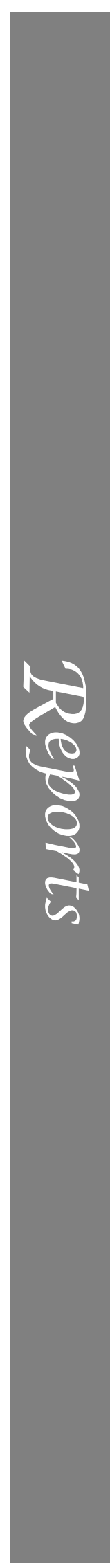


TABLE 1. Model-averaged odds ratio estimates and 95\% confidence limits for covariates in final Sage-Grouse habitat-selection models at each of three spatial scales, southcentral Idaho, USA.

\begin{tabular}{|c|c|c|c|}
\hline \multirow[b]{2}{*}{ Scale and covariate } & \multirow{2}{*}{$\begin{array}{l}\text { Odds } \\
\text { ratio }\end{array}$} & \multicolumn{2}{|c|}{$95 \% \mathrm{CL}$} \\
\hline & & Lower & Upper \\
\hline \multicolumn{4}{|l|}{ Habitat type } \\
\hline Crude protein $(\%)$ & 0.37 & 0.10 & 0.83 \\
\hline Total monoterpenes $(\mathrm{AUC} / 100 \mu \mathrm{g})$ & 0.89 & 0.79 & 0.98 \\
\hline Shrub height $(\mathrm{cm})$ & 0.82 & 0.67 & 0.91 \\
\hline \multicolumn{4}{|l|}{ Patch } \\
\hline Crude protein $(\%)$ & 1.69 & 1.12 & 2.55 \\
\hline Unknown \#1 (AUC/100 $\mu \mathrm{g})$ & 0.60 & 0.37 & 0.96 \\
\hline 1,8-cineole (AUC/100 $\mu \mathrm{g})$ & 1.04 & 0.90 & 1.20 \\
\hline \multicolumn{4}{|l|}{ Plant } \\
\hline Crude protein $(\%)$ & 2.02 & 1.03 & 3.98 \\
\hline 1,8-cineole $($ AUC/100 $\mu \mathrm{g})$ & 0.82 & 0.70 & 0.97 \\
\hline$\alpha$-pinene $(\mathrm{AUC} / 100 \mu \mathrm{g})$ & 0.88 & 0.75 & 1.03 \\
\hline 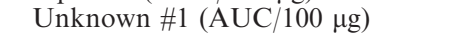 & 0.84 & 0.66 & 1.08 \\
\hline
\end{tabular}

Notes: At the habitat scale, the response is the log odds that a habitat is black sagebrush. At the patch scale, the response is the log odds that a patch within black sagebrush habitat is used. At the plant scale, the response is the log odds that a plant within a used patch is browsed.

protein), seven PSM covariates (Appendix B: Table B1), and two structural covariates (shrub height, shrub canopy cover), we removed collinear variables $(|r|>$ 0.7 , variance inflation factors $>3.0$ ) and fit binary logit models separately at each of three spatial scales. To identify factors associated with selection of habitat type, we treated habitat type (Wyoming big sagebrush or black sagebrush) at random patches as a binary response and the nutrient, PSM, and structural covariates as continuous predictors. To assess selection of patches within a given habitat type, we treated patch type (used or random) as a binary response and the nutrient, PSM, and structural covariates as continuous predictors. Covariate values for used patches were the means of all sagebrush samples (browsed and non-browsed) collected therein. To assess selection of plants within a given patch (i.e., diet selection), we treated plant type (browsed or non-browsed) as a binary response and the nutrient and PSM covariates as continuous predictors. For the analysis of plant selection, we used conditional logit models to control for variation among patches (Compton et al. 2002).

We used a hierarchical information-theoretic approach to model selection and model averaging (Burnham and Anderson 2002, sensu Doherty et al. 2008) within each spatial scale. First, we identified the variables that best represented each of the three predictor categories (nutrient, PSM, structure) by comparing Akaike's Information Criterion values with sample size bias adjustment $\left(\mathrm{AIC}_{\mathrm{c}}\right)$ for all variable combinations within each category (Appendix D: Tables D2-D4). Within the PSM category, we included total monoterpene concentration for comparison with indi- vidual monoterpene covariates, but restricted it to a single-predictor model because of its lack of independence with individual monoterpene covariates. Covariates from the top models in each predictor category were then included in a final round of model selection unless they were ranked below the null (intercept-only) model (Appendix D: Table D1). We weighted final models within $2 \mathrm{AIC}_{\mathrm{c}}$ units of the top model (i.e., $\Delta \mathrm{AIC}_{\mathrm{c}} \leq 2$ ) by Akaike model weight $\left(w_{i}\right)$ to derive model-averaged parameter estimates, and we used unconditional variance for estimating 95\% confidence intervals (Burnham and Anderson 2002). To evaluate model performance, we used 10 -fold cross validation to estimate classification accuracy for the top model at each spatial scale. Statistical analyses were conducted in R version 2.14 ( $R$ Development Core Team 2011) and SAS version 9.2 (SAS Institute 2008).

To screen for cross-scale correlations between spatial scales, we computed bivariate correlation coefficients between scales for all covariates that appeared in top models. We considered $|r|>0.7$ as indicative of significant cross-scale correlation. Additionally, we plotted mean values partitioned by sample category (browsed, non-browsed, random) for covariates shared among top models at the patch and plant scales. Because the covariate values representing the phytochemistry of a given patch were composites of the values of browsed and non-browsed plants within that patch, we expected to see similar values for random and non-browsed samples (i.e., the sample categories not selected by SageGrouse at the patch and plant scales, respectively) if our patch-scale inferences were artifacts of plant-scale selection.

\section{RESULTS \\ Selection of habitat type}

Sage-Grouse used black sagebrush habitat more than expected on the basis of availability (Fisher's exact test: $P<0.0001$, odds ratio $=27.8$; Appendix E: Table E1). The single habitat-type model with $\Delta \mathrm{AIC}_{\mathrm{c}} \leq 2$ included one nutrient covariate (crude protein), one PSM covariate (total monoterpene concentration), and one structural covariate (shrub height; Appendix D: Table D2), with an estimated classification accuracy of $94 \%$. Wyoming big sagebrush contained higher total monoterpene concentrations than black sagebrush (Table 1, Fig. 1). Additionally, Wyoming big sagebrush was characterized by higher crude protein and greater shrub height than black sagebrush (Table 1, Fig. 1). This height difference was the only difference in shrub structure observed at any spatial scale during the study.

\section{Selection of patches}

The two final patch-scale models with $\Delta \mathrm{AIC}_{\mathrm{c}} \leq 2$ contained one nutrient covariate (crude protein) and two PSM covariates (unknown \#1, 1,8-cineole; Appendix D: Table D3). However, the odds ratio estimate for 1,8-cineole differed only slightly from 1 (i.e., logit 

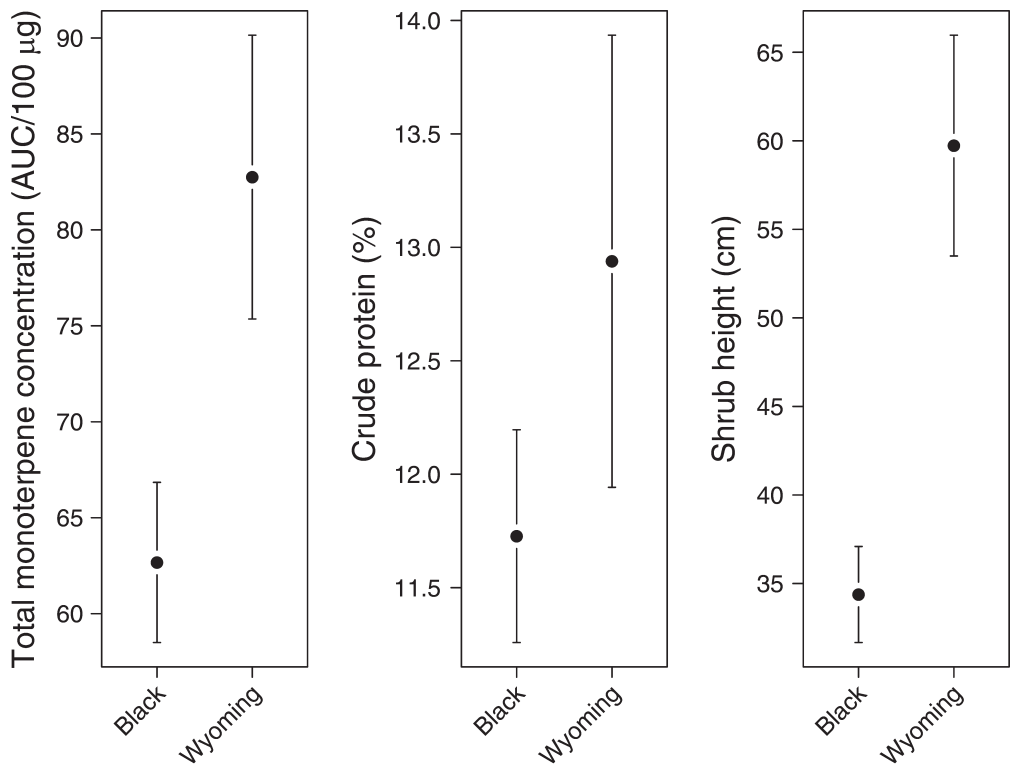

Sagebrush habitat type

FIG. 1. Univariate comparisons (mean and 95\% confidence interval) of total monoterpene concentration (AUC/100 $\mu \mathrm{g}$ dry mass), crude protein (\%), and shrub height (cm) for black sagebrush (Artemisia nova) and Wyoming big sagebrush (A. tridentata wyomingensis) habitats during winter in south-central Idaho, USA. AUC refers to area under the gas chromatogram curve.

coefficient $\approx 0$ ), with a broad confidence interval that substantially overlapped 1 (Table 1). Thus, we concluded that 1,8-cineole lacked inferential value and excluded it from further consideration at the patch scale. The estimated classification accuracy for the top model was $78 \%$. The odds of patch use increased by $69 \%$ for each $1 \%$ increase in crude protein, whereas the odds of patch use decreased by $40 \%$ for each $1 \mathrm{AUC} / 100 \mu \mathrm{g}$ increase in an unidentified monoterpene (unknown \#1; Table 1, Fig. $2 \mathrm{~A})$.

\section{Selection of plants}

The four final plant-scale models with $\Delta \mathrm{AIC}_{\mathrm{c}} \leq 2$ contained one nutrient covariate (crude protein) and three PSM covariates (unknown \#1, $\alpha$-pinene, 1,8cineole; Appendix D: Table D4). Odds ratio estimates

\section{A) Patch selection}

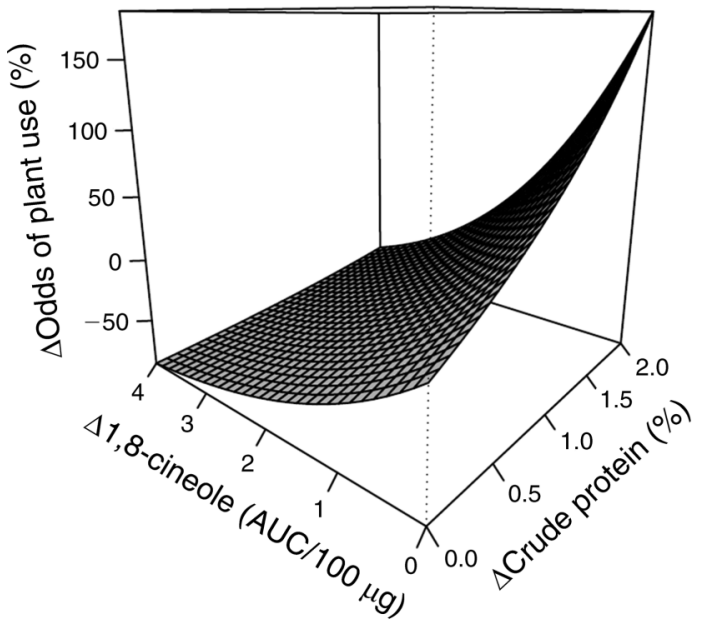

\section{B) Plant selection}

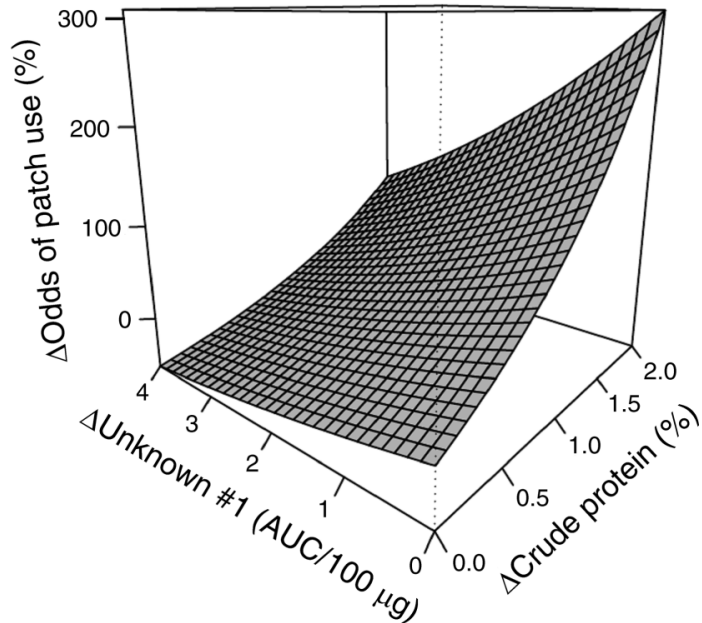

FIG. 2. Response surface depicting the additive effects of increasing plant secondary metabolites (PSM) and nutrient concentrations on the odds of Greater Sage-Grouse (Centrocercus urophasianus) use of (A) patches and (B) plants during winter in black sagebrush (Artemisia nova) habitat, south-central Idaho, USA. Changes in the odds of use were calculated using the top covariates within each spatial scale while holding all other covariates constant. 

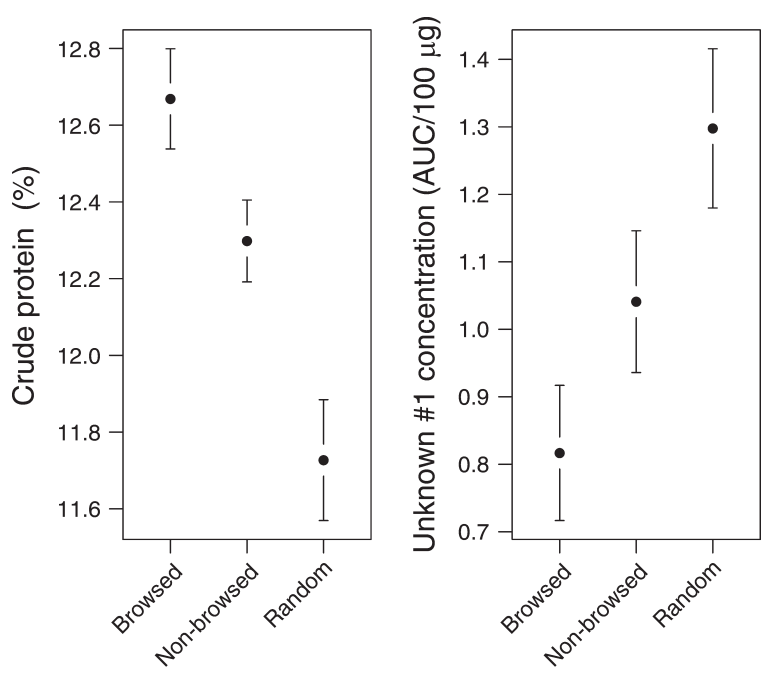

\section{Sample category}

FIG. 3. Values (mean \pm SE) partitioned by sample category (browsed, non-browsed, random) for nutrient (crude protein) and plant secondary metabolite (PSM unknown \#1) covariates occurring in top models in both patch-scale and plant-scale analyses of Greater Sage-Grouse (Centrocercus urophasianus) winter habitat selection in south-central Idaho, USA. Intermediate values for samples in the non-browsed category suggest that observed patch-selection patterns were not artifacts of plant-scale effects.

were less precise for unknown $\# 1$ and $\alpha$-pinene than for 1,8 -cineole, as indicated by $95 \%$ confidence intervals slightly overlapping 1 (Table 1). The estimated classification accuracy for the top model was $80 \%$. The odds of plant use increased by $102 \%$ for each $1 \%$ increase in crude protein, whereas the odds of plant use decreased by $18 \%$ for each $1 \mathrm{AUC} / 100 \mu \mathrm{g}$ increase in 1,8-cineole (Table 1, Fig. 2B).

\section{Cross-scale correlation}

Bivariate correlation coefficients did not indicate the presence of cross-scale correlations $(|r|<0.7)$. Similarly, no relationship was evident $(|r|<0.7)$ between the cumulative PSM values, found to be important at the habitat-type scale, and top covariates at the plant and patch scales. Plots of means partitioned by sample category for covariates shared among top models at the patch and plant scales (crude protein, unknown \#1) indicated that non-browsed samples were intermediate in value relative to browsed and random samples (Fig. 3)

\section{Discussion}

Results were largely consistent with our prediction that selected habitats would be characterized by high nutrient and low PSM concentrations. The sole exception occurred at the habitat-type scale, where nutrient concentrations were lower in the selected habitat type (black sagebrush). PSM differences at that scale may have been sufficiently extreme to negate the influence of nutrients on habitat selection. Total monoterpene concentrations were $32 \%$ higher in Wyoming big sagebrush than in black sagebrush, whereas crude protein concentrations were only $10 \%$ higher (Fig. 1), suggesting that the increase in toxic consequences from high PSM concentrations in Wyoming big sagebrush may have outweighed the increase in nutritional benefit. Additionally, black sagebrush habitat was substantially lower in height than Wyoming big sagebrush habitat (Fig. 1), and the former may thus have provided lower quality thermal or escape cover. Again, the benefit of substantially lower PSMs in black sagebrush habitat may have outweighed any costs of increased thermal or predation risk. Alternatively, habitats characterized by lower shrub heights may have provided structural benefits for Sage-Grouse (e.g., increased ability to detect predators). Selection of low-height sagebrush habitat over sagebrush with greater cover potential has been observed in previous Sage-Grouse studies as well (Hagen et al. 2011), but associated phytochemistry has not been reported previously.

Habitat selection at the patch and plant scales was consistent with our prediction. Patches selected within black sagebrush habitat had higher nutrient concentrations and lower concentrations of individual PSMs (Table 1, Fig. 2). This suggests that use of patches by Sage-Grouse within a selected habitat type is nonuniform and is influenced by nutrients and PSMs. Unlike the habitat-type scale, however, total monoterpene concentrations within black sagebrush habitat did not differ between used $(65.3 \pm 1.88 \mathrm{AUC} / 100 \mu \mathrm{g}$, mean \pm $\mathrm{SE})$ and random $(62.2 \pm 2.06 \mathrm{AUC} / 100 \mu \mathrm{g})$ patches. This is consistent with observations that sagebrush PSM profiles are more similar within taxa than among taxa (Kelsey et al. 1982). Our results suggest that concentrations of individual monoterpenes, rather than cumulative monoterpenes, influence patch selection within a habitat type. In other words, Sage-Grouse selected for the general PSM profile of black sagebrush (habitat-type selection), and then selected for more specific nutrient and PSM differences within that general profile (patch selection).

Similarly, individual plants selected within a given patch were higher in nutrient concentrations and lower in individual PSM concentrations. This suggests finescale habitat selection in which the use of plants within a patch is nonuniform and is influenced by nutrient and PSM characteristics. As with patch selection, total monoterpene concentrations were similar between browsed $(63.7 \pm 2.1 \mathrm{AUC} / 100 \mu \mathrm{g}$, mean $\pm \mathrm{SE})$ and non-browsed $(66.9 \pm 2.4 \mathrm{AUC} / 100 \mu \mathrm{g})$ plants, but individual monoterpene concentrations, in concert with nutrients, appeared to affect plant selection.

An important consideration in multi-scale habitat selection studies is cross-scale correlation (Kristan 2006). Cross-scale correlations can yield inferences at one spatial scale that are actually attributable to effects at a different scale. Although bivariate correlations did 
not indicate substantial cross-scale correlations, it is likely that inferences made at each spatial scale in our study lacked complete independence because we focused on the same phytochemical characteristics at all scales. In particular, because the patch effect was partially a function of plant-scale chemistry, patch-scale parameter estimates may simply have been an artifact of plant-scale effects for the covariates deemed important at both scales (crude protein, unknown \#1). However, the fact that non-browsed samples were intermediate in both crude protein and unknown \#1 relative to browsed and random samples (Fig. 3) suggests that selection was occurring for higher nutrients and lower PSMs at both spatial scales, and that patch-scale effects were not artifacts of cross-scale correlation. Similarly, the lack of substantial correlation between top covariates at the habitat-type scale and those at the smaller scales suggests that selection of habitat type was not solely an artifact of patch or plant selection.

These habitat-use patterns suggest that Sage-Grouse hierarchically selected habitat on the basis of multi-scale heterogeneity in phytochemistry. Within a landscape, Sage-Grouse selected a habitat type (coarse-scale selection) with substantially lower cumulative PSM concentrations than the alternative, despite lower nutrient concentrations and lower vegetation height. Within that habitat type, cumulative PSM concentrations did not vary, but Sage-Grouse selected patches (meso-scale selection) with higher nutrient concentrations and lower individual PSM concentrations. Within those patches, Sage-Grouse selected individual plants (fine-scale selection) with higher nutrient concentrations and lower concentrations of individual PSMs.

Multi-scale habitat selection by a vertebrate herbivore on the basis of phytochemistry has previously been documented only in marsupials within fenced reserves (Moore et al. 2010). Moore et al. (2010) found that koalas (Phascolarctos cinereus) in a fenced reserve were more likely to use patches with higher concentrations of crude protein and less likely to use patches with higher concentrations of a group of phenolic PSMs. These nutrient and PSM characteristics were also associated with koala use of individual trees within those patches (Moore et al. 2010). Our results were consistent with those of Moore et al. (2010) and provide the first evidence for hierarchical habitat selection on the basis of phytochemistry by a vertebrate herbivore outside of fenced reserves. Moreover, we documented habitat selection at a third scale (habitat type) that was not considered in previous studies, and provide the first evidence for the influence of phytochemistry on coarsescale and meso-scale habitat selection by an avian herbivore.

We recommend that investigators routinely consider the functional importance of phytochemistry to avoid incomplete or inaccurate inferences in studies of herbivore habitat selection. This is particularly important for systems in which herbivores specialize on high-
PSM plants, as dietary constraints that limit use of landscapes may exacerbate the impacts of anthropogenic habitat changes. Specialist herbivore species that have suffered significant declines in abundance and available habitat, such as Sage-Grouse (Garton et al. 2011), may be particularly susceptible to environmental changes that decrease nutrient availability or increase PSMs (Lawler et al. 1997), and warrant prioritization for future research and conservation efforts.

\section{ACKNOWLedgments}

We are grateful to L. Cross, T. Ritter, K. Woras, K. Gehlken, S. Agofanov, B. Robb, A. Ullapa, X. Pu, D. Kashin, R. Lott, and R. Lowell for assistance with field and laboratory work. J. R. Belthoff, J. P. Bryant, and an anonymous reviewer provided helpful comments and criticism on the manuscript. R. G. Kelsey provided consultation on the identification of secondary compounds. J. A. Heath provided valuable hydrological insight. The Idaho Department of Fish and Game, Idaho Governor's Office for Species Conservation, Bureau of Land Management (grant \#LO9AC16253 to J. S. Forbey), Boise State University, Wilson Ornithological Society, and NSF Idaho EPSCoR grant \#EPS-0814387 funded this research. All work was conducted under Boise State University IACUC protocol \#006-AC11-003. This is a contribution from Idaho Federal Aid in Wildlife Restoration Project W-160-R.

\section{Literature Cited}

Becker, B. H., and S. R. Beissinger. 2003. Scale-dependent habitat selection by a nearshore seabird, the marbled murrelet, in a highly dynamic upwelling system. Marine Ecology Progress Series 256:243-255.

Bryant, J. P., and P. J. Kuropat. 1980. Selection of winter forage by subarctic browsing vertebrates: the role of plant chemistry. Annual Review of Ecology and Systematics 11:261-285.

Burnham, K. P., and D. R. Anderson. 2002. Model selection and multimodel inference: a practical information-theoretic approach. Springer-Verlag, New York, New York, USA.

Compton, B. W., J. M. Rhymer, and M. McCollough. 2002. Habitat selection by wood turtles (Clemmys insculpta): an application of paired logistic regression. Ecology 83:833-843.

Connelly, J. W., M. A. Schroeder, A. R. Sands, and C. E. Braun. 2000. Guidelines to manage sage grouse populations and their habitats. Wildlife Society Bulletin 28:967-985.

Dearing, M. D., W. J. Foley, and S. McLean. 2005. The influence of plant secondary metabolites on the nutritional ecology of herbivorous terrestrial vertebrates. Annual Review of Ecology, Evolution, and Systematics 36:169-189.

DeGabriel, J. L., B. D. Moore, W. J. Foley, and C. N. Johnson. 2009. The effects of plant defensive chemistry on nutrient availability predict reproductive success in a mammal. Ecology 90:711-719.

Doherty, K. E., D. E. Naugle, B. L. Walker, and J. M. Graham. 2008. Greater sage-grouse winter habitat selection and energy development. Journal of Wildlife Management 72:187-195.

Garton, E. O., J. W. Connelly, J. S. Horne, C. A. Hagan, A. Moser, and M. A. Schroeder. 2011. Greater sage-grouse population dynamics and probability of persistence. Pages 293-381 in S. T. Knick and J. W. Connelly, editors. Greater sage-grouse: ecology and conservation of a landscape species and its habitats. University of California Press, Berkeley, California, USA

Hagen, C. A., J. W. Connelly, and M. A. Schroeder. 2007. A meta-analysis of greater sage-grouse Centrocercus urophasianus nesting and brood rearing habitats. Wildlife Biology $13: 42-50$.

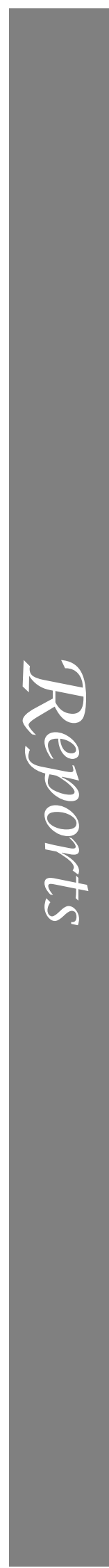


Hagen, C. A., M. J. Willis, E. M. Glenn, and R. G. Anthony. 2011. Habitat selection by greater sage-grouse during winter in southeastern Oregon. Western North American Naturalist 71:529-538.

Johnson, D. H. 1980. The comparison of usage and availability measurements for evaluating resource preference. Ecology 61:65-71.

Kelsey, R. G., J. R. Stephens, and F. Shafizadeh. 1982. The chemical constituents of sagebrush foliage and their isolation. Journal of Range Management 35:617-622.

Kristan, W. B., III. 2006. Sources and expectations for hierarchical structure in bird-habitat associations. Condor 108:5-12.

Lawler, I. R., W. J. Foley, I. E. Woodrow, and S. J. Cork. 1997. The effects of elevated $\mathrm{CO}_{2}$ atmospheres on the nutritional quality of eucalyptus foliage and its interaction with soil nutrient and light availability. Oecologia 109:59-68.

Marsh, J. J , I. R. Wallis, and W. J. Foley. 2005. Detoxification rates constrain feeding in common brushtail possums (Trichosurus vulpecula). Ecology 86:2946-2954.

Mattson, W. J. 1980. Herbivory in relation to plant nitrogen content. Annual Review of Ecology and Systematics 11:119161.

Moore, B. D., I. R. Lawler, I. R. Wallis, C. M. Beale, and W. J. Foley. 2010. Mapping palatability: a koala's eye view of spatial variation in habitat quality. Ecology 91:3165-3176.

R Development Core Team. 2011. R, a language and environment for statistical computing. $\mathrm{R}$ Foundation for Statistical Computing, Vienna, Austria
Rearden, S. N., R. G. Anthony, and B. K. Johnson. 2011. Birth-site selection and predation risk of Rocky Mountain elk. Journal of Mammology 92:1118-1126.

Remington, T. E., and C. E. Braun. 1985. Sage-grouse food selection in winter, North Park, Colorado. Journal of Wildlife Management 49:1055-1061.

SAS Institute. 2008. SAS version 9.2. SAS Institute, Cary, North Carolina, USA.

Schroeder, M. A., J. R. Young, and C. E. Braun. 1999. Greater Sage-Grouse (Centrocercus urophasianus). Number 425 in A. Poole, editor. The birds of North America. Academy of Natural Sciences, Philadelphia, Pennsylvania, USA, and American Ornithologists' Union, Washington, D.C., USA.

Wallestad, R., J. G. Peterson, and R. L. Eng. 1975. Foods of adult sage-grouse in central Montana. Journal of Wildlife Management 39:628-630.

Wambolt, C. L., M. R. Frisina, S. J. Knapp, and R. M. Frisina. 2006. Effect of method, site, and taxon on line-intercept estimates of sagebrush cover. Wildlife Society Bulletin 34:440-445.

Welch, B. L., J. C. Pederson, and R. L. Rodriguez. 1988. Selection of big sagebrush by sage grouse. Great Basin Naturalist 48:274-279.

White, T. C. R. 1978. The importance of a relative shortage of food in animal ecology. Oecologia 33:71-86.

Wiens, J. A. 1989. Spatial scaling in ecology. Functional Ecology 3:385-397.

Wiens, J. A., J. T. Rotenberry, and B. Van Horne. 1986. A lesson on the limitations of field experiments: shrubsteppe birds and habitat alterations. Ecology 67:365-376.

\section{Supplemental Material}

\section{Appendix A}

A photograph of diagnostic bite marks left by Greater Sage-Grouse (Centrocercus urophasianus) on sagebrush, Artemisia spp. (Ecological Archives E094-025-A1)

\section{Appendix B}

Supplementary information on the quantification of monoterpene concentrations in sagebrush (Artemisia spp.) samples, including methods, materials, and a table of gas chromatograph retention times (Ecological Archives E094-025-A2).

\section{Appendix C}

Methods and materials used to quantify total phenolic concentrations in sagebrush (Artemisia spp.) samples (Ecological Archives E094-025-A3).

\section{Appendix D}

Model-selection tables for hierarchical analysis of Greater Sage-Grouse (Centrocercus urophasianus) habitat selection at each of three spatial scales (Ecological Archives E094-025-A4).

\section{Appendix E}

A cross-tabulation of patch type by habitat type for analyzing the selection of sagebrush (Artemisia spp.) habitat type by Greater Sage-Grouse (Centrocercus urophasianus) (Ecological Archives E094-025-A5). 